\title{
Acute pancreatitis in pregnancy: a challenge for the clinician
}

\section{Urvashi Miglani, Nikita Pahuja*, Poonam Laul, V. K. Kadam}

Department of Obstetrics and Gynaecology, DDU Hospital, New Delhi, India

Received: 30 April 2016

Accepted: 02 June 2016

\author{
*Correspondence: \\ Dr. Nikita Pahuja, \\ E-mail: drnikitapahuja87@gmail.com
}

Copyright: (C) the author(s), publisher and licensee Medip Academy. This is an open-access article distributed under the terms of the Creative Commons Attribution Non-Commercial License, which permits unrestricted non-commercial use, distribution, and reproduction in any medium, provided the original work is properly cited.

\begin{abstract}
Acute pancreatitis is one of the very rare events in pregnancy associated with high maternal and fetal morbidity and mortality. We are presenting a case of acute pancreatitis in a 25 year old G2P1L1 at 33 weeks of gestation with previous LSCS who presented to us with hypertension, epigastric pain, vomiting. Investigations revealed hyperamylysemia, hypertriglyceridemia and deranged liver enzymes. After examination and investigations, diagnosis of acute pancreatitis with pregnancy was made. She underwent caesarean section for obstetric hemorrhage and was put in intensive care for 3 days. She was discharged after. 1 week and is under regular follow up for past 6 months.
\end{abstract}

Keywords: Pregnancy, Acute pancreatitis, Hyperlipidemia

\section{INTRODUCTION}

Acute pancreatitis is a serious complication associated with pregnancy occurring in 1 in 1000 pregnancies. ${ }^{1}$ It ranges from mild to serious form, latter being associated with necrosis, abscess, pseudo cyst and multiorgan dysfunction syndrome. Most commonly it is associated with gallstone disease, hypertriglyceridemia, alcohol abuse. ${ }^{2}$ Multiple diagnostic and imaging techniques like abdominal and endoscopic ultrasonography are now available for better diagnosis. ${ }^{3}$

\section{CASE REPORT}

Mrs X, 25 year old female, G2P1L1 with 33 weeks of gestation with previous caesarean section presented in gynaeac emergency, DDU hospital with severe epigastric pain for 2 days which was also associated with vomiting. History of raised B.P. was present for past one week for which patient had been taking antihypertensive. No history of jaundice or cholelithiasis was present. Her personal and medical history was unremarkable.

On examination she was of moderate built and her BMI was 22 . She was dehydrated and mild pallor was present.
There was no icterus or lymphadenopathy. Her PR100/min, BP-140/90 mmHg. Her thyroid, breast, cvs, chest examination was unremarkable.

On Per abdomen examination- uterus corresponded to 34 weeks of gestation, with cephalic presentation, fetal heart rate-150-160/min L/E-NAD. Abdominal and obstetric USG was done which showed bulky pancreas with moderate amount of free fluid in left upper quadrant with live pregnancy 33 weeks 4 days of gestation with cephalic presentation, placenta fundoposterior well above the OS.

Investigations revealed $\mathrm{Hb}-8 \mathrm{gm} / \mathrm{dl}$, TLC- $14,800 / \mathrm{mm}^{3}$, Coagulation profile was normal, Serum amylase -1252 units, Serum lipase -2764 units, serum triglycerides -600 $\mathrm{mg} / \mathrm{dl}$. Based on the history and investigations the probable diagnosis of acute pancreatitis with pregnancy was made.

Patient was admitted in critical unit and was managed conservatively with IV fluids, nasogastric suctioning, bowel res, use of analgesics and antispasmodics. She was administered steroids for accelerating fetal lung maturity. Two days later she complained of BPV. Her BP-150/100 
mmHg, PR-120/min, P/A -UT-34weeks soft, non- tender, internal examination revealed long unaffected cervix with slight bleeding. USG revealed 34 weeks live pregnancy with retro placental clots. As the neonatal intensive care unit was well equipped to manage neonates of 33 weeks gestation, decision for emergency LSCS was taken. Emergency LSCS was done. An alive male baby of 2.25 $\mathrm{kg}$ was delivered and was shifted to NICU.100-200 $\mathrm{cc}$ of retro placental clots were removed. Patient had postpartum haemorrhage intraoperative. Apart from the medical management, Hayman's sutures were applied and uterine artery ligation was done. Patient was shifted to Intensive care unit in postoperative phase. As she became hemodynamically stable she was shifted ward after 3 days. Her post-operative day3 investigations werecomplete haemogram and bood biochemistry was normal and pancreatic enzymes showed falling titre (serum amylase-874 units, serum liase-1243 unit's serum triglyceride-460 mg/dl) Patient was discharged after stich removal on PND-8 in a good condition and is under follow up.

\section{DISCUSSION}

Acute pancreatitis is rarely encountered during pregnancy. Pancreatitis can occur any time during pregnancy but $52 \%$ of cases are found in $3^{\text {rd }}$ trimester and rarely occur during postpartum period. Mostly it is associated with gall stone disease, hypertriglyceridemia, alcohol abuse. ${ }^{1}$

During pregnancy the volume of gall stones increases and flow of bile decreases. Increased estrogen and bile cholesterol found in pregnancy leads to gall bladder smooth muscle relaxation enhancing bile stasis. Gall stones can migrate in the common bile duct causing temporary or permanent obstruction of pancreatic duct leading to rise in hydrostatic pressure and activation of digestive enzymes within the pancreas. ${ }^{1}$ Rise in acute pancreatitis from triglyceridemia in pregnancy is highest in third trimester and is supposed to be the more severe form of pancreatitis than gall stones. ${ }^{4}$

Most commonly associated symptoms are nausea, vomiting, and abdominal discomfort. Elevated amylase and Lipase are hallmark of pancreatitis. ERCP and CECT are gold standard for diagnosing common bile duct stasis and pancreatitis in non-pregnant patients. MRI can be safely used during pregnancy and can be preferred if cause of acute abdomen cannot be made on ultrasonography and benefit outweighs the risk. ${ }^{4,5}$

Conservative management should be the mainstay of treatment in acute pancreatitis which includes dietary restriction of fat, lipid lowering agents, IV fluids, nasogastric suctioning, bowel rest, use of analgesics and antispasmodics. Surgical treatment should only be considered in case of pancreatic enlargement or necrosis or no improvement after 2-3 days of conservative management. $^{3}$

\section{CONCLUSION}

Acute pancreatitis with pregnancy is a challenging problem and should be suspected in patients with nonobstetric abdominal pain. Timely prompt and accurate diagnosis improves the outcome of mother and fetus with acute pancreatitis with pregnancy.

Funding: No funding sources

Conflict of interest: None declared

Ethical approval: Not required

\section{REFERENCES}

1. Ducarme G, Maire F, Chatel P, Luton D, Hammel P. Acute pancreatitis during pregnancy: a review. Journal of Perinatology. 2014;34:87-94.

2. Wang GJ, Gao CF, Wei D, Wang C, Ding SQ. Acute pancreatitis: etiology and common pathogenesis. World J Gastroenterol. 2008;15(12):1427-30.

3. Sun Y, Fan C, Wang S. Clinical analysis of 16 patients with acute pancreatitis in the third trimester of pregnancy. International Journal of Clinical and Experimental Pathology. 2013;6(8):1696-1701.

4. Abdullah B, Pillai TK, Cheen LH, Ryan RJ. Severe acute pancreatitis in pregnancy. Case Reports in Obstetrics and Gynecology. 2015;Article ID 239068.

5. Serpytis M, Karosas V, Tamosauskas R. Hypertriglyceridemia-induced acute pancreatitis in pregnancy. JOP J Pancreas (Online). 2012;13(6):677-80.

Cite this article as: Miglani U, Pahuja N, Laul P, Kadam VK. Acute pancreatitis in pregnancy: a challenge for the clinician. Int J Reprod Contracept Obstet Gynecol 2016;5:2448-9. 